\title{
Éditorial
}

\section{FORAGE INTERACTIF}

Il est économiquement très important pour les opérateurs pétroliers de minimiser le temps entre la découverte d'un champ et sa mise en production. Il leur faut également optimiser le taux de récupération de l'huile en place par un positionnement efficace des drains dans le réservoir. Pour remplir ces objectifs, les informations recueillies lors des opérations de forage ont une importance stratégique. Elles constituent en effet un outil de choix pour réduire les incertitudes géologiques et donc optimiser le schéma de développement du gisement. Elles permettent également un meilleur contrôle des opérations de forage et donc une réduction des risques et des coûts.

Depuis une dizaine d'années, l'IFP, en étroite collaboration avec ses partenaires industriels, a conduit des programmes de recherche visant à résoudre les différents problèmes technologiques associés aux mesures en cours de forage, à leurs traitements pour en extraire des informations pertinentes et à leurs utilisations pour améliorer la description géologique du gisement et la trajectoire des puits.

Le dossier «Forage interactif » présenté dans ce numéro de Oil \& Gas Science and Technology Revue de l'Institut français du pétrole fait le point sur les évolutions récentes des technologies de forage et sur les apports, en termes d'outils d'aide à la décision pour les ingénieurs de forage et de réservoir, d'une utilisation en temps réel des différents types de mesures qui peuvent être effectuées au cours des opérations de forage. De nombreux développements technologiques sont en cours et les progrès déjà réalisés soulignent le large potentiel du «forage interactif » :

- Il est à présent possible d'optimiser les paramètres opérationnels du forage grâce à une détection précoce des vibrations anormales et des dysfonctionnements hydrauliques. La méthodologie des arbres de diagnostic permet, en intégrant le savoir-faire des foreurs, d'analyser les signaux issus du mud logging et de les transformer en alarmes. Ces méthodes ont été testées avec succès sur chantier et sont en cours d'extension à d'autres dysfonctionnements tels que l'instabilité des parois du puits.

- La sismique en cours de forage est également très prometteuse : plusieurs essais sur champ ont démontré que l'utilisation de l'outil de forage comme source sismique peut fournir une image de la formation en-dessous de l'outil de forage. Cette technologie devrait, dans le futur, constituer un moyen efficace d'optimisation de la trajectoire des puits.

- Enfin, des travaux sont en cours pour concevoir des modèles qui, à partir des diagraphies réalisées en cours de forage et associées à des mesures sur carottes, permettront d'établir un «log géomécanique » et donc d'estimer les propriétés mécaniques des formations forées.

Les nouvelles technologies de l'information et de la communication sont le complément indispensable à ces innovations technologiques. Elles ont, en effet, rendu possible la distribution et le partage des grands volumes de données issues des mesures en cours de forage entre les différents métiers concernés, c'est-à-dire foreurs, géophysiciens, géologues et ingénieurs réservoir. Différents logiciels spécifiques sont en cours de développement afin de permettre l'utilisation de ces données pour enrichir et remettre à jour, en temps réel, les différents modèles applicatifs. 
Le développement du forage interactif nécessite donc de relever un ensemble de challenges technologiques, tant en ce qui concerne le hardware que le software. Les résultats attendus sont très attractifs mais ils ne pourront être atteints que par une étroite collaboration entre technologues et opérationnels, comme l'illustrent les articles qui suivent.

Jacqueline Lecourtier Directeur Scientifique de l'IFP 


\section{Editorial}

\section{INTERACTIVE DRILLING}

Petroleum production companies recognise the considerable economic importance of minimising the delay between discovery of an oil field and the start of production. They also need to optimise the recovery of oil in place by creating an efficient drainage architecture in the reservoir. Data collected during drilling operations is of strategic importance in fulfilling these objectives. The information gained provides a vital tool for increasing the precision of the geological description of the field and thus for optimising its development. It also allows better control of drilling operations, leading to reductions both in risks and in costs.

Over the last decade $I F P$, in close cooperation with its industrial partners, has carried out research programmes aimed at resolving problems associated with the technology of measurement while drilling, with the interpretation of data to extract relevant information, and with the use of this information to improve both the geological description of the field and the well path.

The dossier dealing with "Interactive Drilling" included in this issue of Oil \& Gas Science and Technology - Revue de l'Institut français du pétrole examines recent progress in the technological aspects of drilling and in the real-time use, in the form of tools to support decision making by drilling and reservoir engineers, of the various measurements that can be carried out during drilling operations. Many technological developments are under way and the progress already achieved demonstrates the great potential of interactive drilling:

- It is now possible to optimise drilling conditions during operation by early detection of anomalous vibrations and hydraulic malfunction. The use of diagnosis trees, integrating the know-how of drillers, allows the signals from mud logging to be interpreted and converted to alarms. These methods have been successfully tested in the field and extension of their application to other types of malfunction, such as borehole instability, is under way.

- Seismic while drilling is also extremely promising: several field tests have shown that using the drilling tool as a seismic source can yield an image of the formation beyond the drilling tool. This technology should, in the future, provide an effective means of optimising the well path.

- Finally, work is in progress on model building, associating data from logging while drilling with results of core analysis, to construct "geomechanical logs" from which the mechanical properties of the formations being drilled can be assessed.

Recently developed information and communication technologies are an indispensable complement to these technological innovations. They have allowed distribution and sharing of the enormous quantities of data, coming from measurements while drilling, between the different professions involved: geophysicists, geologists and reservoir engineers. A variety of specific software is under development which will allow these data to be used to improve and update, in real time, the various application-based models. 
Development of interactive drilling thus has to meet a number of challenges in the realisation of both hardware and software. Very exciting are results expected which, as illustrated by the following papers, can only be achieved by close collaboration between technical and operational teams.

Jacqueline Lecourtier IFP Scientific Director 